\title{
Research on Bachelor Degree Education and Application-oriented Innovative Talent Cultivation System
}

\author{
Hansong Yang \\ School of Engineering \\ Huanghe Science and Technology College \\ Zhengzhou, China \\ Hua Yue \\ Henan Boda Microwave Equipment Co., Ltd. \\ Zhengzhou, China
}

\author{
Luoming Zhang \\ School of Engineering \\ Huanghe Science and Technology College \\ Zhengzhou, China
}

Tengkun Li

Undergraduate enrolled in 2016

Department of Process Equipment and Control Engineering Huanghe Science and Technology College

Zhengzhou, China

\begin{abstract}
In the new era of transformation development of institutions of higher education, in order to meet the need of regional economic development and social and economic construction, the key of talent cultivation in colleges and universities is to produce application-oriented talents who can meet social requirements. It is necessary to cultivate special talents with certain vocational competitive ability. Practical and effective measures should be taken in terms of talent cultivation. On the basis of mastering basic theories, students' practice ability should also be strengthened, thus problems concerning personal technical ability are solved and social and economic development's requirements for talents are meet. As a result, application-oriented talents who can meet social requirements are produced. Building an innovative talent cultivation system and strengthening cultivation of students' application-oriented innovation ability have important theoretical and practical significance in professional talent cultivation. This paper puts forward the establishment of an application-oriented innovative talent cultivation system, which has important theoretical significance for professional research.
\end{abstract}

Keywords-application-oriented; innovative talent cultivation; curriculum system; teaching staff

\section{INTRODUCTION}

Higher education conducts a series of teaching reforms from elite cultivation to popular education with a final purpose of cultivating application-oriented talents adapting to social and regional economic development. Although thousands of colleges and universities publish tens of thousands of research results of talent cultivation reform nationwide and they do a lot of research work, years of practice proves that the effect is tiny. All colleges and universities nationwide try to revise and improve their talent cultivation program, put forward various reform measures and programs, and adjust curriculum and outline. Our country even invests plenty of money in major colleges and universities for their excellent engineer cultivation plan. Seeing from current result, it is far from expectation. After graduation, students' engineering sense and ability are poor. They don't have the basic condition to be an engineer, their practical ability is bad and they don't have the basic quality to do engineering work. Fundamentally speaking, cultivated talents can't meet social requirement. Local colleges conduct cultivation of application-oriented innovative talents, conforming to our country's overall situation of and policies on strategic adjustment on talent cultivation. At the same time, it is a new requirement of adaptation to local and regional economic development for application-oriented innovative talent cultivation. Fundamentally speaking, the location of talent cultivation is a kind of talent cultivation specification which conforms to objective reality in combination with regional economic development and society's actual requirement for talents according to educational body's actual situation.

In order to adapt to requirements of transformation development and innovative entrepreneurship development, this paper aims at prominent contradictions between social requirement for talent and talent cultivation supply of institutions of higher education, combines with the author's years of teaching reform research results and experience and summarizes a set of application-oriented innovative talent cultivation experience in the process of carrying out research projects of provincial level, namely Henan Province General Institutes of Higher Education Undergraduate Engineering Education Talent Cultivation Mode Reform Pilot MajorMachine Design and Manufacturing and Automation and Henan Province Special Comprehensive Reform Experimental Unit-Machine Design and Manufacturing and Automation Major. On this basis, in combination with the author's experience of guidance in college students' extracurricular scientific and technological activities and implementation of 
"Five Ones" project among students in recent several years, a set of innovation method of talent cultivation comes into being.

\section{CURRENT SituAtion OF TALENT CULTIVATION IN INSTITUTIONS OF HIGHER EDUCATION}

At present, there is severely unreasonable tendency in curriculum system and structure of institutions of higher education in China. Teaching content is old, course theory and practice severely fall apart, there is less and less practical teaching content and cultivation of practical ability, and the emphasis is on theory instead of practice. There is obvious emphasis on theoretical research and neglect of application. Colleges fail to implement various practice links, engineering consciousness training and engineering ability cultivation. Upon graduation, most graduates have poor engineering consciousness and poor practical ability. Thus, there is a great gap between graduates' quality and ability and social jobs' required quality and ability. Therefore, it becomes a top problem for institutions of higher education to strengthen talent cultivation and cultivate application-oriented innovative talent adapting to requirement of social development at the moment.

\section{BASIC FEATURES OF APPLICATION-ORIENTED INNOVATIVE TALENT}

The so-called application-oriented innovative talents refer to students applying learned major knowledge in an innovative way to solve relevant engineering problems of their major according to basic requirements of the major. This requires students to well master basic knowledge and theory required by the major during their stay at school. Besides, practical teaching training platform should be established based on ability cultivation to provide a teaching system conforming to actual need of society and being relevant to the major.

\section{HOW TO BUILD AN APPLICATION-ORIENTED INNOVATIVE TALENT CULTIVATION SYSTEM}

According to basic features of application-oriented innovative talent cultivation, construction of applicationoriented innovative talent cultivation system should cater to application. Namely, on the basis of mastering learned major knowledge, take cultivation of students' practice ability and innovative ability as the fundamental starting point of curriculum system construction. Curriculum teaching system and teaching content construction should be done according to the major's basic requirement of practical application ability and innovative ability. Theoretical curriculum system and practical curriculum system should be set up around improving students' practical application ability and innovative ability. Strictly speaking, in the formulation of application-oriented innovative talent cultivation plans, the setting of curriculum system depends on whether it is useful for cultivation of students' practical and innovative ability. In terms of talent cultivation type, application-oriented innovative talents should be cultivated according to requirements of regional economic and social development. We should cultivate this kind of talents who have good humanistic quality, high scientific literacy, innovative spirit, open-minded consciousness, basic knowledge, theory and skill of the major, high engineering practical ability and vocational adaptation ability. They can also do certain technical work in a certain direction of their professional field. According to features of bachelor degree education and application-oriented innovative talent cultivation, the system is built as shown in "Table I".

TABLE I. BACHELOR DEGREE EDUCATION AND APPLICATIONORIENTED INNOVATIVE TALENT CULTIVATION CURRICULUM SYSTEM

\begin{tabular}{|c|c|c|}
\hline $\begin{array}{l}\text { Overall } \\
\text { Structure of } \\
\text { Curriculum }\end{array}$ & Module & Detailed Content \\
\hline \multirow{2}{*}{$\begin{array}{l}\text { Composition } \\
\text { of } \\
\text { professional } \\
\text { knowledge }\end{array}$} & Basic theory & $\begin{array}{l}\text { Basic knowledge and basic } \\
\text { skills mastered in } \\
\text { undergraduate course of the } \\
\text { major }\end{array}$ \\
\hline & $\begin{array}{ll}\text { Experiment } & \text { and } \\
\text { practical training and } \\
\text { design part }\end{array}$ & $\begin{array}{l}\text { Matched training part of } \\
\text { major course }\end{array}$ \\
\hline \multirow{2}{*}{$\begin{array}{l}\text { Application } \\
\text { ability }\end{array}$} & $\begin{array}{l}\text { Relevant comprehensive } \\
\text { skill practice project of } \\
\text { the major }\end{array}$ & $\begin{array}{l}\text { Major comprehensive } \\
\text { practice project training }\end{array}$ \\
\hline & $\begin{array}{l}\text { University-industry } \\
\text { cooperation relevant to } \\
\text { the major }\end{array}$ & $\begin{array}{l}\text { Field training, } \\
\text { internship, etc. }\end{array}$ \\
\hline $\begin{array}{l}\text { Innovation } \\
\text { ability }\end{array}$ & $\begin{array}{l}\text { Relevant innovation } \\
\text { practice with training of } \\
\text { the major }\end{array}$ & $\begin{array}{l}\text { Special project of innovative } \\
\text { practice and comprehensive } \\
\text { training }\end{array}$ \\
\hline
\end{tabular}

In order to adapt to regional economic development and provide application-oriented employment positions, major system should conform to object location of construction and development. Talent cultivation plan has to timely track changes in technical need and talent need.

Major knowledge is a systematic and relatively stable content system which can be used to understand and deal with certain problems after learning. Based on different specifications of talent and different majors, there are certain differences in knowledge system and structure.

Undergraduate major's knowledge system should set up a major knowledge theoretical system according to basic requirements of national education department's undergraduate talent cultivation specification. It should consist of "basic knowledge, core knowledge and expanded knowledge", three levels in total. "Basic knowledge" is musthave knowledge of public basic course and specialty course and it should be mastered before entering the phase of having major courses. "Core knowledge" is major knowledge with core competitiveness of this major, which differs from other majors. "Expanded knowledge" aims at expanding students' scope of knowledge and makes them know about relevant disciplinary knowledge of the major.

Ability structure refers to a person's method, means and attitude of dealing with and solving problems after postnatal efforts. According to actual situation and specific behavior feature, ability structure can fall into different ability types. Due to different training degrees, people's ability structures are different.

Application ability refers to ability structure and it consists of "basic ability, core occupational ability and expansion capability", three parts in total. The three parts namely are basic ability of major, core ability of major and major 
expansion capability to continue to improve. Corresponding capability framework should be built according to capability level. Capability cultivation should be built according to a certain system. The first is building a technique and skill training system relevant to major knowledge system to some extent. Build 1 to 2 comprehensive content systems for major courses according to discipline features and provide necessary training for students. The second is building enterprise environment or build a comprehensive training system which can provide training in various aspects of this major according to features of academic discipline. Innovate ability training. In the process of comprehensive training, in terms of actual problems, necessary improvements should be done in other identical or similar contents to achieve distinctive effect. In a word, application-oriented innovative talent cultivation mainly has a view to cultivate practical technical and skilled talents in order to improve students' "combat" capability.

In the process of application-oriented innovative talent cultivation, teacher plays a vital role, especially in the informatization era of rapidly updated knowledge. Teachers can't be content with things as they are. If their teaching content is unchanged for many years, knowledge content is only restricted to the discipline, they use traditional teaching method and means, they lack modern teaching means, they stick to convention, and they don't learn new knowledge, with time goes on, they will be sifted out by tide of new era. Therefore, teachers have to learn new knowledge and explore new methods constantly. Ancient people say: "It's better to teach one to fish than giving him fish". School teaching should take cultivation of students' ability and cultivation of students' independent thinking ability and ability to analyze and solve actual problems as the objective, passing on students the ability and skill required by independent learning. In order to adapt to the ever-changing society, teachers themselves should be composite talents with certain science, management and law knowledge. Liberal art teachers should have basic scientific quality, and science and engineering teachers should have necessary humanistic knowledge. College teachers should be good at many things and expert in one with necessary cultural and artistic quality.

\section{CONCLUSION}

In conclusion, in order to cultivate application-oriented innovative talents, we need good academic discipline curriculum systems and practice systems. We need to establish a professional comprehensive training platform and we should have a team adapting to talent cultivation. Only by doing these, can we cultivate application-oriented innovative talents meeting requirements of regional economic development and society.

\section{ACKNOWLEDGMENT}

This paper is a sponsored project of national college student off-campus practice teaching base, brand major of civilian-run college of Henan Province, Henan Province general institutes of higher education undergraduate engineering education talent cultivation mode reform pilot major, institution of higher education "specialty comprehensive reform experimental unit" project, characteristic specialty of Henan Province and talent cultivation mode reform research project of Huanghe Science and Technology College, etc.

\section{REFERENCES}

[1] Dai Xuan-jun, Wu Zhi-qiang. Research on the applied talent training scheme for mechanical major in local college. Higher Education forum. Vol.6,pp.33-36,2012

[2] P.Wang. Teaching reform and practicing for mechanical professionals, China juvenile, Vol. 29,pp.209,2011.

[3] Chen Guo-jin. On innovative teaching practice of engineering university students, Research and Exploration in Laboratory.Vol. 29 , pp.9597, 2010.

[4] Sun quan-ping, Liu yuan-wei. Research of specialty on mechanical designing-manufacturing and atomization . Higher Education forum. Vol.6,2005.

[5] Liang Ya-qin. Report on the Personnel Training of Major in Mechanical Engineering. Equipment Manufacturing Technology. Vol.1, pp.209211,2013

[6] Chen Yafang. Teaching Idea of College Teachers in the Contemporary Era[J]. China University Teaching, 2003, (1).

[7] Yuan Zuwang. What Teaching Idea should College Teacher Change[J]. China University Teaching, 2004, (8).

[8] Liang Jun. Build Practical and Innovative New Universities[J]. Education Modernization, 2006,(5). 